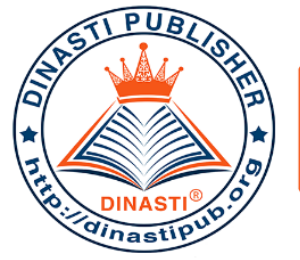

\title{
DETERMINANTS OF BOND RATING [CASE STUDY ON CONSUMER FINANCE COMPANIES OF INDONESIA STOCK EXCHANGE IN 2018 PERIOD
}

\author{
Rahmi Hafidania ${ }^{1}$, Hakiman ${ }^{2}$ \\ 1) Mercu Buana University, Jakarta, Indonesia \\ ${ }^{2)}$ Mercu Buana University, Jakarta, Indonesia
}

\begin{tabular}{|c|c|}
\hline $\begin{array}{c}\text { ARTICLE INFORMATION } \\
\text { Received: } 24^{\text {th }} \text { July } 2020 \\
\text { Revised: } 5^{\text {th }} \text { August } 2020 \\
\text { Issued: } 22^{\text {th }} \text { August } 2020 \\
\text { Corresponding author: First Author } \\
\text { E-mail: } \\
\text { rahmihafidania@gmail.com } \\
\text { hakiman.thamrin@mercubuana.ac.id }\end{array}$ & $\begin{array}{l}\text { Abstract: This study aims to analyze the determinants of } \\
\text { bond rating for case studies on consumer finance companies } \\
\text { listed on the IDX. The factors studied are firm size, liquidity, } \\
\text { profitability, leverage, and growth. The sample collection } \\
\text { technique uses a purposive sampling method. The data used } \\
\text { descriptive statistical analysis with total } 22 \text { sample } \\
\text { companies. Data analysis uses multiple linear regression } \\
\text { analysis. The results showed that firmsize and liquidity had a } \\
\text { significant positive effect, while the leverage had a negative } \\
\text { effect on bond rating. Profitability and growth had no effect } \\
\text { on bond rating. The implication of this study is that investors } \\
\text { can make information related to bond rating as one of the } \\
\text { references before making an investment and to minimize the } \\
\text { risk of default. In order for bonds to remain competitive and } \\
\text { attractive to investors, companies need to improve company } \\
\text { performance and bond rating. In addition, companies also } \\
\text { need to increase assets and strengthen capital for business } \\
\text { turnover. These ways have been proven affecting the } \\
\text { company's obligation rating. For further study, it is expected } \\
\text { to be able to test other variables that are determinants of bond } \\
\text { rating because the coefficient of determination of this study is } \\
63.70 \% \text {, which means the remaining } 36.30 \% \text { bond rating are } \\
\text { influenced by factors outside this study. } \\
\text { Keywords: Bond rating, firm size, liquidity, profitability, } \\
\text { leverage, and growth. }\end{array}$ \\
\hline
\end{tabular}

\section{INTRODUCTION}

The development of bond capitalization in Indonesia is increased. This can be seen from the market capitalization value of corporate bonds that has continued to increase over the last five years. The table below is a development of the value of bond capitalization occured in Indonesia : 


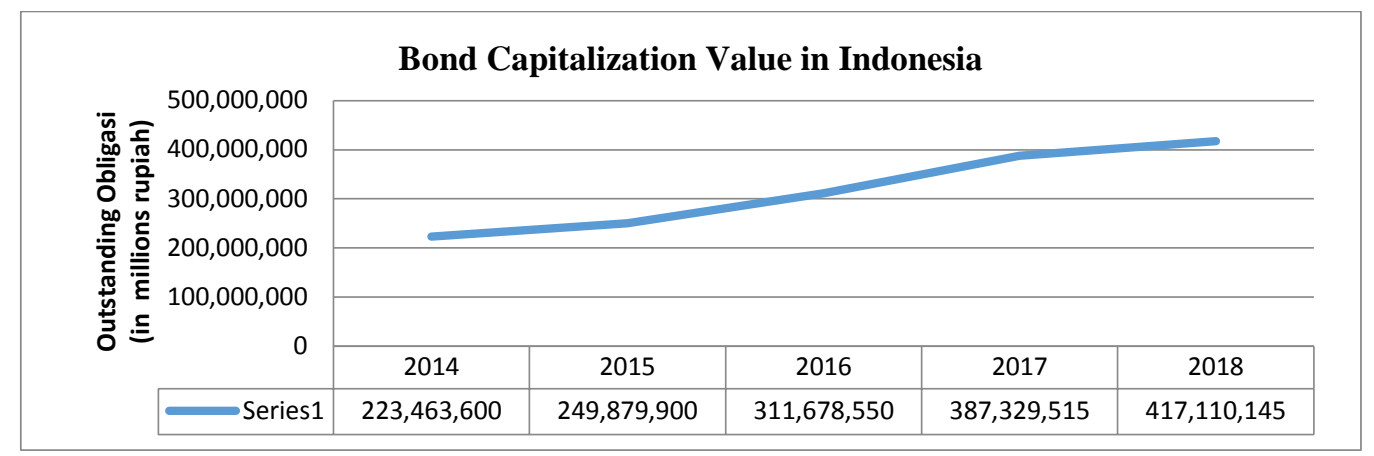

Figure 1. Development of Bond Value in Indonesia

Source: Financial Services Authority

According to Purwaningsih (2010), "investment in bonds is more safe compared to stocks because stock volatility is higher than bonds, and bonds also offerrate of a positive return and fixed income [1]. "Bonds have an advantage when compared to stocks, where bondholders get guaranteed profits because they are not bound by the company" (Manurung, 2008) [2].

The advantage of bond investment is that the investor will get interest and principal in accordance with the time and the amount of interest agreed at the beginning between the investor and the company that issues the bond. Another advantage is that in the event of liquidation, the bondholder has the first rights to the company's assets.

Bond investment has the risk of default by a company in paying its obligations (default risk). Therefore, before investing, investors should look for information about the company's financial condition. One of the ways is investors can find out about bond rating. According to Ayudha and Bambang's research (2019), that "bond rating is one of the references of investors in making feasible decisions about investing in bonds" [3].

The phenomenon of bond downgrades occurred in one of the consumer finance companies that failed to pay the obligations, namely PT Sunprima Nusantara Financing Company, known as SNP Finance, which failed to pay medium term notes (MTN) with a value of Rp 1.85 trillion. "There are two series of MTNs whose interest has not been paid, namely MTN V SNP Phase II with a principal amount of Rp 200 billion and issued in February 2018, the coupon rate is $10.5 \%$ and will mature on February 9, 2020, while MTN III / 2017 series B released in November 2017 and will mature on November 13, 2019, MTN III was released worth Rp 50 billion with an interest rate of $12.12 \%$ per year. So the total interest payment obligations that failed to be Rp. 6.75 billion. In 2017 PT Sunprima Nusantara has a bond rating in the idA- category, but the rating was downgraded to idSD as of May 2018" [4]. (PEFINDO, October 14, 2019).

In addition, "PT Batavia Prosperindo Finance and Sustainable Bond Rating I Phase II / 2017 Bonds I and Phase II / 2018 Sustainable Bonds II in circulation were affirmed that they had a bond rating in the category of "idBBB, but PEFINDO revised the prospects for the company rating of PT Batavia Prosperindo Finance Tbk (BPFI ) becomes "negative" from "stable" in 2018. A negative sign (-) indicates a weak rating in each rating category. The rating is lowered if the company's new orders deteriorate significantly due to tightening 
funding sources, as this can reduce its market presence in the industry and cause a weaker assessment of its business risk profile" [4]. (PEFINDO, October 14, 2019).

Based on the phenomenon, investors should pay attention to bond rating before investing so that the risk of default can be minimized. So through bond rating, investors can find out information and signals about the probability of default or failure of a company.

Research conducted by Dali et al (2015) states that "there are several factors that can affect bond rating are institutional ownership, managerial ownership, independent commissioners, audit committees, corporate governance perception index (CGPI), leverage, profitability, and liquidity quality" [5]. Other studies have produced "bond age (maturity), auditor reputation which significantly influences predicting corporate bond rating", while liquidity, growth and productivity variables have no effect on bond rating" (Vina,2017) [6].

This study will examine the factors of firm size, liquidity, profitability, leverage, and growth. The selection of variables in this study refers to previous studies which the results of the research show are still inconsistent. This study is based on financial statements by calculating financial ratios.

Based on the above explanation, then the following problem formulation in this study are :

1. Does firm size effect the bond rating?

2. Does liquidity effect the bond rating?

3. Does profitability effect the bond rating?

4. Does leverage effect the bond rating?

5. Does growth effect the bond rating?

\section{LITERATURE REVIEW}

\section{Signaling Theory}

Signaling theory was introduced by Spence in his research entitled Job Market Signaling [7]. Spence (1973) argues that "the sign will gives a signal, the sender (the owner of the information) tries to provide relevant pieces of information that can be utilized by the recipient" [7]. According to Brigham and Houston (2011: 184) "signaling theory is a behavior of company management in giving instructions to investors regarding management's views on the company's prospects for the future" [8]. "When the information is announced and all market participants have received the information, market participants can interpret and analyze the information as a good signal (bad news) or bad news (bad news)" (Jogiyanto, 2010: 392) [9].

\section{Asymmetric Information Theory}

Asymmetric Information definition is "a situation where managers have different information about the company's prospects than those owned by investors" (Brigham and Houston, 1998) [10]. "Asymmetry information explains that information inequality occurs if one party from a company has better information than the other party" (George Arkelof, 1970) [11]. Before investing, investors need to find out information about a company's financial condition so that it can be used as a reference in determining the feasibility of 
investment activities. Information such as bond rating is considered very important because it can provide signals and information on whether the bonds are in the investment grade category or not and know the level of risk.

\section{Bond rating}

According to Priyo and Ubaidillah (2000) "bond rating are made to provide information to investors whether the investment chosen, especially investments in the form of bonds, is a risky investment or not" [12]. Bond ratings are rated by rating agencies that can illustrate the risk of default. In general, bond ratings are divided into two classifications are investment grade (AAA, AA, A and BBB) and non investment grade (BB, B, CCC and D). "Investment grade is a category of a company that is considered to have sufficient ability to repay all of its debts, while non investment grade is categorized companies are not feasible to be invested by investors "(PEFINDO) [4].

There are several bond rating agencies in the world such as Moody's Investor Service, and Standard \& Poor's Corporation. One of the bond rating agencies in Indonesia is PT Pemeringkat Efek Indonesia (shortened to PT PEFINDO). The table below is a credit rating classification according to S\&P, Moody's, and PEFINDO :

Table 2. Classification of Bond Ratings

\begin{tabular}{|c|c|c|c|}
\hline & S\&P & Moody's & PEFINDO \\
\hline \multicolumn{4}{|c|}{ Invesment Grade } \\
\hline Highest Grade & AAA & Aaa & AAA \\
\hline Higher Grade & $\mathrm{AA}(+$, none, -$)$ & $\mathrm{Aa}(1,2,3)$ & $\mathrm{AA}(+$, none, -$)$ \\
\hline $\begin{array}{l}\text { Upper Medium } \\
\text { Grade }\end{array}$ & $\mathrm{A}(+$, none, -$)$ & $\mathrm{A}(1,2,3)$ & $\mathrm{A}(+$, none, -$)$ \\
\hline Medium Grade & $\mathrm{BBB}(+$, none,- $)$ & $\operatorname{BBB}(1,2,3)$ & $\mathrm{BBB}(+$, none,- $)$ \\
\hline \multicolumn{4}{|l|}{$\begin{array}{l}\text { Speculative } \\
\text { Grade }\end{array}$} \\
\hline $\begin{array}{l}\overline{\text { Lower Medium }} \\
\text { Grade }\end{array}$ & $\mathrm{BB}(+$, none, -$)$ & $\mathrm{BB}(1,2,3)$ & $\mathrm{BB}(+$, none, -$)$ \\
\hline Speculative & $\mathrm{B}(+$, none, -$)$ & $\mathrm{B}(1,2,3)$ & $\mathrm{B}(+$, none, -$)$ \\
\hline Poor Standing & $\mathrm{CCC}(+$, none, -$)$ & $\operatorname{CCC}(1,2,3)$ & $\mathrm{CCC}$ \\
\hline $\begin{array}{l}\text { Highly } \\
\text { Speculative }\end{array}$ & $\mathrm{CC}$ & $\mathrm{Ca}$ & \\
\hline Lowest Quality & $\mathrm{C}$ & $\mathrm{C}$ & \\
\hline In Default & D & & $\mathrm{D}$ \\
\hline
\end{tabular}

\section{Firm size}

Source: Jorion dan Zhang (2007) [13] dan PEFINDO [4]

Brigham \& Houston (2011: 4) defines "company size as the size of a company as measured by total assets, total sales, total profits, tax expenses and others" [8]. In this study, firmsize is proxied by using total assets.

\section{Liquidity}

\section{Size $=$ Ln Total Aset}

According to Kasmir (2014: 130) "the liquidity ratio or also called the working capital ratio is a ratio that can be used to measure how liquid a company is" [14]. "One of the benefits of calculating the liquidity ratio is to determine the company's ability to pays its debts" (Kasmir, 2012: 132) [15]. Liquidity is represented by current ratio measurement.

\section{Current Ratio $=\underline{\text { Current Assets }}$}

Current Liabilities 


\section{Profitability}

Profitability is "the ratio used to assess a company's ability to generate profits" (Kasmir, 2015: 196) [16]. Companies with large profits have better ratings because the large profits generated are interpreted to be able to cover their debts. This is supported by the statement of Burton (2003) that "a high level of profitability will reduce the risk of insolvency (the company's inability to pay debts)" [17]. Profitability is represented by return on assets (ROA).

$$
\text { ROA }=\frac{\text { Profit after tax }}{\text { Total Assets }}
$$

\section{Leverage}

The solvency ratio (leverage) is "the ratio that can be used to measure the extent to which a company's assets are financed with debt" (Kasmir, 2016: 151) [18]. According to Kasmir (2016: 157), that "debt to equity ratio is a ratio that can be used to assess debt with equity" [18]. To measure this ratio using the debt to equity ratio calculation. "The greater the value of a company's leverage, the greater the risk of failure of a company, the lower the company's leverage, the better the rating given to the company (Burton, Adam and Hardwick, 2003)" [17].

\section{Growth}

Debt to Equity Ratio = Total Debt Total Equity

Growth Ratio is "a ratio that can describe the ability of a company to maintain its economic position in the midst of economic growth and its business sector" (Kasmir, 2012: 107) [15]. According to Steven Pottier and David Sommer (in Widya Andry, 2005), "business growth has a positive relationship with rating decisions and grades for the next rating to be given to companies, because growth indicates the prospects of future cash flow performance and increases value economics" [19]. Growth variable is calculated using indicators of sales change.

$$
\text { Sales }=\frac{\mathrm{St}-\mathrm{St}-1}{\mathrm{St}-1} \times 100 \%
$$

The following is the framework of this research is:

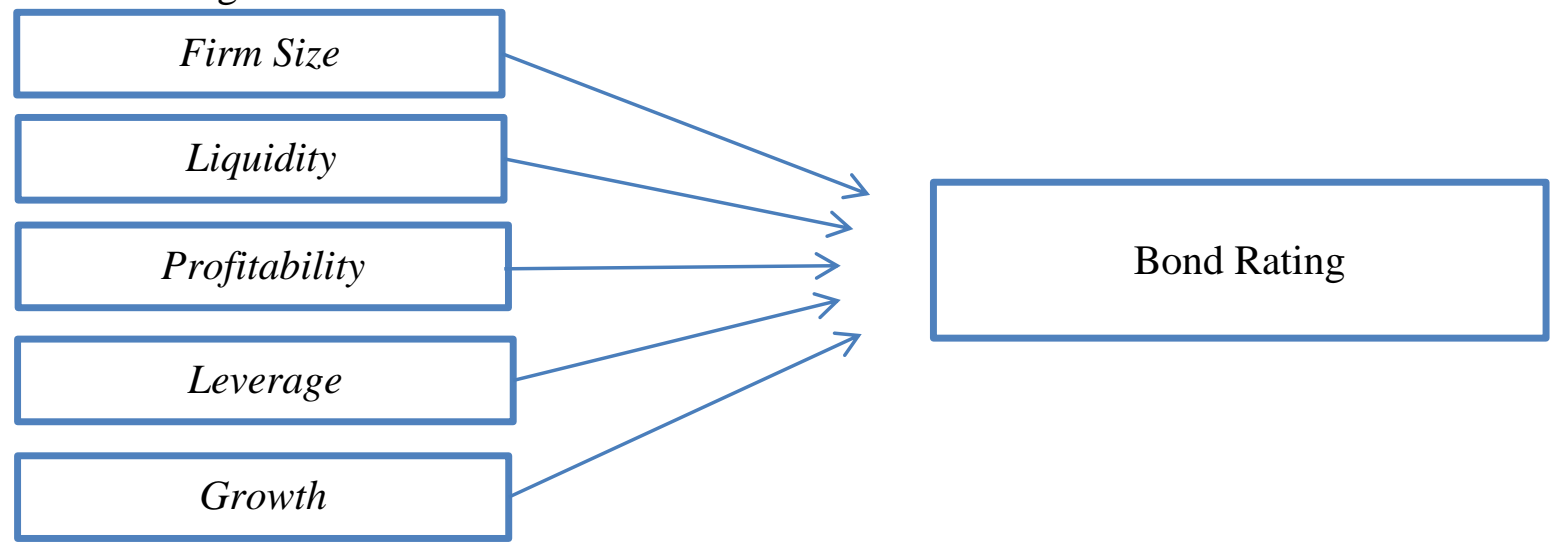

Figure 2. Research model 
Based on the above research model, the following hypotheses in this study are:

$\mathrm{H} 1$ : There is an effect of firm size on the bond rating.

$\mathrm{H} 2$ : There is an effect of liquidity on bond rating.

H3: There is an effect of profitability on bond rating.

$\mathrm{H} 4$ : There is an effect of leverage on bond rating.

H5: There is an effect of growth on bond rating.

\section{RESEARCH METHODS}

The dependent variable is bond rating. The measurement of the dependent variable is giving a rating to each rating issued by PT PEFINDO. The measurement scale uses an ordinal scale. The independent variables are firm size, liquidity, profitability, leverage, and growth. The scale of measurement of independent variables uses financial ratios sourced from annual financial statements.

This research uses quantitative research methods. To find out the influence between variables using hypothesis testing. The method of analysis uses multiple linear regression analysis.

The population in this study are consumer finance company listed in Indonesian Stock Exchange (IDX) and issued bonds in 2018. The sampling was done by purposive sampling method. the total sample is 22 consumer finance companies.

Data collection techniques using secondary data. Data sourced from audited annual financial statements, obtained from ICMD (Indonesian Capital Market Directory), and bond ratings are sourced on the website www.pefindo.co.id [4].

\section{FINDINGS AND DISCUSSION}

\section{Analysis of Multiple Linear Regression}

Table 3. Analysis of Multiple Linear Regression

\begin{tabular}{|c|c|c|c|c|}
\hline Model & Coefficient & $\mathbf{t}$ & Sig. & Keterangan \\
\hline \multicolumn{5}{|l|}{ Model 1} \\
\hline (Constant) & 0.129 & 0.887 & 0.390 & \\
\hline Firm Size & 0.546 & 2.897 & 0.012 & Berpengaruh Positif \\
\hline Liquidity & 0.371 & 2.241 & 0.042 & Berpengaruh Positif \\
\hline Profitabilitas & -0.019 & -0.128 & 0.900 & Tidak Berpengaruh \\
\hline Leverage & -0.358 & -2.207 & 0.044 & Berpengaruh Negatif \\
\hline Growth & -0.094 & -0.618 & 0.547 & Tidak Berpengaruh \\
\hline
\end{tabular}

Source: PEFINDO and Audited Financial Statements, processed

From the table above so the following regression equation is :

\begin{tabular}{|c|}
\hline Bond Ratings $=0,129+$ 0,546 Firm Size + 0,371 Liquidity $-0,019$ Profitability \\
- 0,358 Leverage - 0,094 Growth
\end{tabular}




\section{R-square Coefficient (R2)}

Table 4. R-Square Determination Coefficient Results

\begin{tabular}{|c|c|c|c|}
\hline $\begin{array}{c}\text { Dependent } \\
\text { Variable }\end{array}$ & Independent Variable & $\begin{array}{c}\text { R } \\
\text { Square }\end{array}$ & $\begin{array}{c}\text { Adjusted } \\
\text { R Square }\end{array}$ \\
\hline Bond rating & Firm Size, Liquidity, Profitability, Leverage, \\
Growth & 0,798 & 0,637 \\
\hline
\end{tabular}

Source: PEFINDO and Audited Financial Statements, processed

Based on table 4. above, the value of Adjusted R Square is $=0.637$. This shows that $63.70 \%$ Bond Rating (Y) is influenced by firm Size, liquidity, profitability, leverage, growth, while the rest $(100 \%-63.70 \%)$ is $36.30 \%$ Bond Rating (Y) is influenced by other factors outside this study.

\section{Test Statistics $\mathbf{t}$}

Table 5. Bond Rating (Y) Multiple Linear Regression Results

\begin{tabular}{|c|c|c|c|c|}
\hline Model & Coefficient & $\mathbf{T}$ & Sig. & Explanation \\
\hline \multicolumn{5}{|l|}{ Model 1} \\
\hline (Constant) & 0.129 & 0.887 & 0.390 & \\
\hline Firm Size & 0.546 & 2.897 & 0.012 & Positive (+) Significant \\
\hline Liquidity & 0.371 & 2.241 & 0.042 & Positive (+) Significant \\
\hline Profitability & -0.019 & -0.128 & 0.900 & Has no effect \\
\hline Leverage & -0.358 & -2.207 & 0.044 & Negatif (-) effect \\
\hline Growth & -0.094 & -0.618 & 0.547 & Has No effect \\
\hline
\end{tabular}

Source: PEFINDO and Audited Financial Statements, processed

Based on table 5 above, the following interpretation results are :

1. Effect of Firm Size on Bond Rating (Y).

Table 5 above shows that firm size has a significant effect on bond rating (Y). The coefficient value is positive, it is means $54.60 \%$ has an effect on the bond rating. Thus Firm Size has a significant positive effect on Bond Rating (Y), Hyphotesys 1 is accepted.

The results of this study are consistent with the study of Sejati (2010) [21] .According to Devi, et al (2007) states that "small companies have a greater risk when compared with large companies that have greater assets" [20]. The greater the company's assets, it can be interpreted that the company has the ability to fulfill its debts.

2. Effect of Liqudity on Bond Rating (Y).

The table above shows that liquidity has a significant effect on bond rating (Y). The coefficient value is positive in the amount of $37.10 \%$ affecting the bond rating (Y). So Hypthesys $_{2}$ is accepted, which means liquidity has a significant positive effect on bond rating (Y)".

The results of this study support research conducted by Burton et al (2000) [17] and Almilia \& Devi (2007) [20] which state that "a high level of liquidity will indicate a strong company's financial condition so that it will financially influence the prediction of bond rating". "The company's ability to pay off short-term liabilities indicates that the company is 
in a liquid state" (Sejati, 2010) [21]. Assuming that current assets can meet short-term obligations.

3. Effect of Profitability on Bond Rating (Y).

The table above shows that profitability has no effect on bond rating (Y). The coefficient value is negative indicating that the direction of the relationship between profitability and bond rating is negative of $1.90 \%$. So profitability has no effect on bond rating $(\mathrm{Y})$, then the hypothesis ${ }_{3}$ is rejected".

4. Effect of Leverage on Bond Rating (Y).

The table above shows that leverage has a affect on bond rating (Y). The coefficient value is negative, indicating that the direction of the relationship between leverage and the bond rating is negative. Show that $35.8 \%$ affecting the bond rating (Y). Hyphotesys 4 is accepted, which means leverage has a negative effect on bond rating (Y)".

This result is consistent with research by Wijayanti and Priyadi (2014) [22], and Tisya (2017) [23] that "companies with high levels of leverage tend to have low ability to pay off the debt". The greater the value of this ratio, the greater the risk of default. Conversely, the smaller the ratio, the better the bond rating a company.

5. Effect of Growth on Bond Rating (Y).

The table above shows that growth has no effect on the bond rating (Y). The coefficient value is negative that is equal to $-0,094$ which indicates that the direction of the relationship between growth and the bond rating is negative of $9.40 \%$. So Growth has no significant effect on the Bond Rating (Y), the hypothesis 5 is rejected.

Table 6. Conclusions of Bond Ranking (Y) Multiple Linear Regression Results

\begin{tabular}{|c|c|c|c|c|c|}
\hline Model & Coefficient & $\mathbf{T}$ & Sig. & Explanation & Hypothesis \\
\hline \multicolumn{6}{|l|}{ Model 1} \\
\hline $\begin{array}{l}\text { - Effect of Firm Size on Bond } \\
\text { Rating }\end{array}$ & 0.546 & 2.897 & 0.012 & $\begin{array}{l}\text { Positive (+) } \\
\text { Significant }\end{array}$ & $H_{1}$ is accepted \\
\hline $\begin{array}{l}\text { - Effect of Liqudity on Bond } \\
\text { Rating }\end{array}$ & 0.371 & 2.241 & 0.042 & $\begin{array}{l}\text { Positive (+) } \\
\text { Significant }\end{array}$ & $\mathrm{H}_{2}$ is accepted \\
\hline $\begin{array}{l}\text { - Effect of Profitability on } \\
\text { Bond Rating }\end{array}$ & -0.019 & -0.128 & 0.900 & Has no effect & $\mathrm{H}_{3}$ is rejected \\
\hline - Effect of Leverage on Bond & -0.358 & -2.207 & 0.044 & $\begin{array}{l}\text { Negatif (-) } \\
\text { effect }\end{array}$ & $\mathrm{H}_{4}$ is accepted \\
\hline $\begin{array}{l}\text { - Effect of Growth on Bond } \\
\text { Rating }\end{array}$ & -0.094 & -0.618 & 0.547 & $\begin{array}{l}\text { Has No } \\
\text { effect }\end{array}$ & $\mathrm{H}_{5}$ is rejected \\
\hline
\end{tabular}

Source: PEFINDO and Audited Financial Statements, processed

\section{CONCLUSION AND SUGGESTION}

\section{Conclusions}

Based on the result of the analysis and discussion, it can be concluded that firm size and liquidity has a positive significant effect on bond rating, while the leverage has a negative effect on bond rating on consumer finance companies listed on the Indonesia Stock Exchange 
(BEI). Profitability and growth has no effect on bond rating on consumer finance companies listed on the Indonesia Stock Exchange (BEI).

Based on the result of this research, it can be concluded that before investing, investors should know the condition of a company. One of them is knowing information about bond rating issued by rating agencies because it can be used as a benchmark for investors to decide whether bonds are categorized as investment grade or non-investment grade so that investors can consider the level of risk.

\section{Suggestions}

The following suggestions and implications that can be given are :

a) For Investors

Investment in bonds has a risks, one of them is the risk of default by a company in meeting its obligations (default risk). Information about bond rating can be information for investors in knowing the level of investment risk. With this research, it is expected to be a reference for investors as consideration in making investment decisions.

b) For Future Researchers

Value of adjusted $\mathrm{R}$ square can be interpreted bond rating is influenced by variables firm size, liquidity, profitability, leverage, growth by $63.70 \%$, while the remaining $36.30 \%$ is influenced by other external factor this study. For further research, it is suggested to be able to conduct research on other variables that determine bond rating. It is also expected that research in other sectors are conducted so that the results obtained are getting better.

c) For the Company

Companies need to know the determinants of bond rating. Based on research results, companies need to improve performance, total assets and strengthen capital for business turnover. That is because it has been proven to affect bond rating.

\section{REFERENCE}

[1] Purwaningsih, A. 2008. "Pemilihan Rasio Keuangan Terbaik Untuk Memprediksi Peringkat Obligasi: Studi pada Perusahaan Manufaktur yang Terdaftar di BEJ," J. Kinerja, vol. 12.

[2] Manurung, A. 2008. "Hubungan Rasio-Rasio Keuangan dengan Rating Obligasi".

[3] Weniasti A., and Marsoem, B. S. 2019. "The Effect of Bonds Rating, Profitability, Leverage, and Firm Size on Yield to Maturity Corporate Bonds," Int. J. Innov. Sci. Res. Technol. Mercu Buana University.

[4] "Pefindo Credit Rating Agency." www.pefindo.co.id.

[5] Dali, Chandra Ly, et al. 2015. "Pengaruh Mekanisme Corporate Governance dan Rasio Keuangan terhadap Peringkat Obligasi," J. Finesta, vol. 3 No 1, pp. 30-35.

[6] Vina. 2017. "Analisis Pengaruh Reputasi Auditor, Umur Obligasi, Likuiditas, Growth, Dan Produktivitas Perusahaan Terhadap Peringkat Obligasi Pada Pertumbuhan Go Public Yang Terdaftar Di Bursa Efek Indonesia,” J. Akintansi Bisnis, XV (30), 104-125.

[7] Spence, M. 1973. “Job Market Signaling,” Q. J. Econ., doi: 10.2307/1882010.

[8] Brigham, Eugene F dan Joel F. Houston. 2011. Dasar-dasar manajemen Keuangan (Buku 2 Edisi 1Brigham, E. F., \& Houston, J. F. Dasar-dasar manajemen Keuangan (Buku 2 - Edisi 11). In Salemba Empat.1).

[9] Jogiyanto. 2010. "Teori portofolio dan analisis investasi (edisi ketujuh)," Yogyakarta BPFE.

[10] Brigham, Eugene F dan Joel F. Houston. 1998, Dasar-Dasar Manajemen Keuangan. Jakarta: 
Salemba Empat.

[11] Akerlof, George A. 1970. "The Market for 'Lemons'. Quality Uncertainty and the Market Mechanism," Q. J. Econ., vol. 84, no. 3, pp. 488-500.

[12] Pratomo, Eko Priyo, dan Ubaidillah N. 2000. Reksadana: Solusi Perencanaan Investasi di Era Modern. Jakarta: PT.Gramedia Pustaka Utama.

[13] Zang, G dan Jorion, P. 2007. "Information Effects of Bond Rating Changes: The Role of the Rating Prior to the Announcement," J. Fixed Income, doi: 10.3905/jfi.2007.683317.

[14] Kasmir. 2014. Laporan Keuangan Bank. Jakarta : PT Raja Grafindo Persada.

[15] Kasmir. 2012. Laporan Keuangan Bank. Jakarta : PT Raja Grafindo Persada.

[16] Kasmir. 2015. Laporan Keuangan Bank. Jakarta : PT Raja Grafindo Persada.

[17] Burton, B., Adam Mike dan Hardwick P. (2000). "The determinants of credit ratings in the United Kingdom insurance industry," J. Bus. Financ. Account., doi: 10.1111/14685957.00007.

[18] Kasmir. 2016. Laporan Keuangan Bank. Jakarta : PT Raja Grafindo Persada.

[19] Andry, Widya. 2005. "Analisis Faktor-Faktor yang Mempengaruhi Prediksi Peringkat Obligasi," Bul. Ekon. dan Monet. dan Perbankan.

[20] Almilia, Luciana Spica dan Vieka Devi. 2007. "Faktor-Faktor yang Mempengaruhi Prediksi Peringkat Obligasi Pada Perusahaan Manufaktur Yang Terdaftar Di Bursa Efek Jakarta," Proceeding Semin. Nas. Manaj. SMART Bandung.

[21] Sejati, Grace Putri. 2010. "Analisis Faktor Akuntansi dan Non Akuntansi Dalam Memprediksi Peringkat Obligasi Perusahaan Manufaktur," J. Ilmu Adm. dan Organ., pp. 70-78.

[22] Wijayanti, Indah dan Priyadi. (2014). "Faktor-Faktor Yang Mempengaruhi Peringkat Obligasi," J. Ilmu Ris. Akunt., vol. 3 No. 3.

[23] Lukman, Tisya U. 2017. "Analisis Faktor-Faktor yang Mempengaruhi Peringkat Obligasi di Bursa Efek Indonesia," Management. 